Original Research Paper

\title{
Peran Pasar Digital Di Era Pandemi Pada Wirausaha Muda Di Banyumulek
}

\author{
Irma Setiawan $^{1 *}$, Ibrahim ${ }^{2,7}$, Isnaini $^{3}$, Muallifah Anugrah ${ }^{4}$, Murojatul Aslamiah $^{5}$, Nurhayati $^{6,7}$ \\ ${ }^{1}$ Program Studi Bahasa Indonesia, Fakultas Keguruan dan Ilmu Pendidikan, Universitas Muhammadiyah \\ Mataram, Mataram, Indonesia \\ ${ }^{2}$ Program Studi Geografi, Fakultas Keguruan dan Ilmu Pendidikan, Universitas Muhammadiyah Mataram, \\ Mataram, Indonesia \\ ${ }^{3}$ Program Studi Ilmu Hukum, Fakultas Hukum, Universitas Muhammadiyah Mataram, Mataram, Indonesia \\ ${ }^{4}$ Prodi Studi Manajemen Sumber Daya Perairan, Fakultas Sains dan Teknologi Universitas Muhammadiyah \\ Sinjai, Sinjai, Indonesia \\ ${ }^{5}$ Program Studi Teknik sipil, Fakultas Teknik, Universitas Muhammadiyah Mataram, Mataram, Indonesia \\ ${ }^{6}$ Program Studi Teknologi Hasil Pertanian, Fakutas Pertanian, Universitas Muhammadiyah Mataram,Mataram, \\ Indonesia \\ ${ }^{7}$ Program Studi Magister Ilmu Lingkungan, Program Pasca Sarjana, Universitas Muhammadiyah Mataram, \\ Mataram, Indonesia
}

https://doi.org/10.29303/jpmpi.v3i2.1161

Sitasi: Setiawan, I., Ibrahim., Isnaini., Anugrah, M., Aslamiah, M \& Nurhayati. (2021). Pelatihan Pengolahan Sampah berbasis Masyarakat sebagai Alternatif Penanganan Limbah di Desa Penimbung. Jurnal Pengabdian Magister Pendidikan IPA 4(4)

\section{Article history}

Received: 10 Oktober 2021

Revised: 30 Oktober 2021

Accepted: 17 November 2021

*Corresponding Author: Irma

Setiawan, Universitas

Muhammadiyah Mataram,

Mataram, Indonesia

Email: irmasetiawan9@gmail.com

\begin{abstract}
Desa Banyumulek merupakan wilayah dengan mayoritas penduduk memiliki mata pencaharian sebagai pengrajin gerabah. Masyarakat Banyumulek mengalami kesulitan pemasaran hasil kerajinan gerabah semenjak pandemi Covid19. Produk-produk gerabah banyak tidak laku dan batal dieskpor karena kesulitan biaya/modal. Para pengusaha rerata beralih profesi untuk menutup biaya produksi gerabah yang tidak berproses selama pandemi. Kondisi usaha dan kesiapan warga Banyumulek menghadapi pandemi sangat rendah. Toko-toko konvensional sepi dan hanya beberapa kunjungan dalam satu pekannya. Solusi Pasar Digital (Digital Marketing/Market Place) sebagai formula alternatif dalam mengatasi kerisis penjualan hasil kerajinan gerabah. Model pasar digital yang dibentuk berdasarkan skala jangkuan pemasaran. Beberapa vendor menjadi lokasi operasional pasar digital yang dicanangkan oleh pemuda Banyumulek. Metode pendekatan yang digunakan dalam penelitian ini, yakni deskriptif kualitatif dengan memokuskan perhatian pada fenomena sosial - ekonomi masyarakat. Pengumpulan data dilakaukan dengan observasi, sosalisasi, dan dokumentasi. Hasil penelitian menunjukkan (1) jenis-jenis potensi wirausaha Desa, (2) perancangan sistem pasar digital desa, dan (3) aktualisasi kegiatan pasar digital mamsyarakat desa.
\end{abstract}

Keywords: Desa Banyumulek, pasar digital, gerabah

\section{Pendahuluan}

Banyumulek atau Desa Gerabah merupakan wilayah yang terletak di Kecamatan Labuapi, Lombok Barat. Desa ini dikenal sebagai desaa pengrajin gerabah di wulayah Nusa Tenggara
Barat (NTB). Beragam hasil kerajinan tidak hanya dipasarkan di wilayah Nusa Tenggara Barat, melainkan di ekspor ke beberapa wilayah di Indonesia, seperti: Pulau Jawa, Sumatera, Kalimantan, dan Sulawesi. Sebagian besar kebutuhan pasar nasional terhadap gerabah Banyumulek, sebagai produk properti hotel dan 
penginapan. Pemasaran gerabah tidak hanya merambah lokal dan regional, juga diekspor ke mancanegara meliputi wilayah daratan Eropa dan Amerika. Produk-produk gerabah secara rutin di sortir oleh pelaku usaha gerabah di Banyumulek yang dikoordinir oleh pemerintah desa dan karang taruna, untuk melakukan rekapitulasi produk ekspor. Kegiatan ekspor regional dan internasional menjadikan bisnis kerajinan gerabah ini bertahan di era modern saat sekarang ini.

Situasi usaha gerabah di Desa Banyumulek mengalami perubahan drastis semenjak Pandemi Covid-19 melanda dunia. Sentimen negatif konsumen dan pasar regional dan internasional mengalami tren negatif. Berdsarkan data catatan kantor desa Banyumulek terjadi penurunan hingga $80 \%$. Artinya, hampir tidak ada perputaran bisnis gerabah di Banyumulek. Kondisi ini telah banyak mengubah arah usaha masyarakat Banyumulek, yang semula berkonsentrasi pada kerajinan gerabah, beralih ke mata pencaharian lainnya. Fenomena ini tentu menjadi keprihatinan bersama. Usaha yang sudah menakar dan berkembang dari tahun 70-an mulai tergerus oleh pandemi yang tak berujung ini.

Kondisi manufaktur berupa bahan pembuatan gerabah, seperti rotan, tanah liat, dan tanah campuran adonan, seperti: tanah liat stoneware clays, tanah liat fire clays, dan tanah liat Earthenware teronggok tidak terpakai di setiap sisi desa. Remaja desa dan karang taruna pada sesi observasi, mereka banyak memberikan pendapat bahwa perputaran bisnis gerabah sudah mulai mengecil, dan tidak seperti masa-masa sebelum pandemi. Beragam cara promosi sudah dilakukan, mulai dari mengurangi ambang batas harga, sampaia dengan menerapan bonus di setiap pembelaian, akan tetapi tetap saja sepi pembeli. Usaha ekspor yang dilakukan juga tidak menemukan tanda jadi, dikarenakan biaya atau tarif ekspor yang jauh lebih mahal dari biaya pada saat kondisi normal atau sebelum pandemi.

Di samping itu, terdapat persoalan lainnya, yakni tahun 2018 di bulan Juli hingga Agustus tepatnya bermula pada 29 Juli 2018, terjadi gempa Lombok yang berkekuatan $6,4 \mathrm{Mw}$ pada pukul 06.47 WITA dengan pusat gempa berada di $47 \mathrm{~km}$ timur laut Kota Mataram dan kedalaman $24 \mathrm{~km}$. Bencana alam gempa bumi terus melanda pulau Lombok hingga bulan Agustus 2018 tepatnya pada 5 Agustus 2018 gempa bumi dengan kekuatan 7,0 $\mathrm{Mw}$ membuat pulau Lombok semakin terpuruk. Tidak terkecuali dengan Desa Banyumulek sendiri. Pengunjung dan turis yang awalnya sangat ramai berkunjung menjadi berkurang jumlahnya akibat dari munculnya rasa takut untuk bekunjung ke Pulau Lombok akibat dari bencana alam ini. Belum pulih dari gempa 2018, di tahun 2020 kerajinan gerabah Banyumulek kembali terpuruk. Memasuki awal tahun 2020, dunia digoncangkan oleh sebuah bencana dan pandemi penyakit yang tidak hanya berdampak di suatu daerah saja tetapi merata ke seluruh dunia. Pandemi penyakit tersebut dikenal dengan penyakit virus covid-19. Kemunculan pandemi covid-19 membuat seluruh lini kehidupan menjadi terhenti seketika. Sektor perekonomian berhenti berputar, setiap orang sibuk memutar otak untuk mencari cara memenuhi kebutuhan hidup di masa Pandemi. Para pengunjung dan turis Desa Banyumulek yang memang berkurang jumlahnya sejak 2 tahun terakhir tidak lagi datang berkunjung. Masyarakat Banyumulek kehilangan sumber mata pencaharian dari hasil gerabahnya. Banyak dari mereka yang akhirnya memilih berpindah mata pencaharian dan mencari pekerjaan lain hanya untuk memenuhi kebutuhan sehari-hari. Kerajinan gerabah pun mulai terancam eksistensinya, salah satu contohnya adalah munculnya generasi Banyumukek yang tidak tahu cara membuat gerabah. Hal ini dikarenakan orang tua tidak mengajari anaknya bagaimana cara membuat gerabah dengn alasan menjual gerabah tidak akan cukup untuk memenuhi kebutuhan hidup dan mendorong anak- anaknya untuk ke depannya mencari pekerjaan lain selain daripada membuat kerajinan gerabah.

Desa Banyumulek juga (Hadi, Sulhan, Nurul Hidayati Indra Ningsih, 2021) memiliki potensi lainnya yang hanya ada satu-satunya di Desa Banyumulek. Salah satunya adalah Banyumulek memiliki wisata religi yang dikenal dengan "Masjid Kembar Menara Tunggal" yang menjadi satu-satunya di NTB bahkan satu-satunya di Indonesia. Terletak di arah barat dari kantor desa Banyumulek dengan jarak 400 m sebagai jantung Desa Banyumulek. Rencananya jika menara tunggalnya nanti jadi akan diadakan bedug terbesar di NTB. Di samping itu Desa Banyumulek juga memiliki makam tertua yang disebut makam "Bakumulek". Ada juga sumur tertua yang pertama tertua di Desa Banyumulek tepatnya di 
Banyumulek Barat. Saat ini sumur tertua tersebut hanya sebagai tempat kunjungan saja. Ke depannya sumber mata air sumur tersebut akan dikemas sedemikian rupa untuk dijadikan air khas Banyumulek dan dijadikan oleh-oleh bagi pera pengunjun dan turis yang berdatangan. Ada pula taman bunga, tepatnya terletak di Dusun Gubuk Baru sekitar 1,5 hektar. Desa Banyumulek juga terus melestarikan budaya sholawat dalam mewujudkan Desa Banyumulek sebagai desa sholawat. Selain dari potensi gerabahnya potensipotensi lain di atas tetapi belum banyak dikenal, oleh karenanya permasalahan lain yang ditimbul adalah permasalahan pemasaran yang masih kurang. Promosi yang kurang sudah harus dikembangkan dalam bentuk promosi digital atau Digital Marketing.

Permasalahan berikutnya yang turut menimpa Desa Banyumulek yaitu permasalahan stunting yang terjadi pada usia anak-anak. Jumlah stunting di Desa Banyumulek cukup tinggi. Menurut keterangan dari kepala Desa Banyumulek Bapak Jamiludin, S.I.P., sebanyak 200 anak di Banyumulek menjadi korban stunting. Anak-anak pada usia sekolah dasar masih ada yang belum bisa membaca dan menulis dengan baik, ini menjadi salah satu pengaruh dari keberadan stunting di Desa Banyumulek. Persoalan stunting ini belum mendapat perhatian khusus di Desa Banyumulek, karena fokus Desa Banyumulek adalah pada persoalan perekonomian.

Ragam persoalan tersebut menjadi keprihatinan bersama terhadap kebertahanan wirausaha tradisional masyarakat Sasak di Desa Banyumulek, Lombok Barat. Kami dari tim, dosen Universitas Muhammamdiyah Mataram (UMMAT) melaksanakan salah satu kewajiban Tri Dharma Perguruan Tinggi, yakni Pengabdian kepada masyarakat. Melalui kegiatan ini, tim menargetkan masyarakat Banyumlek, dalam hal ini Karang Tarunan dan pemerintah desa bersinergi membangun Electronic Commerscial (E-Comers), berupat market place atau pasar digital yang diletakkan pada vendor-vendor belanja lokal dan nasional.

\section{Metode}

Kegiatan ini dilaksanakan pada Bulan September 2021 yang diikuti oleh karang taruna dan para pemuda diseluruh dusun yang terdapat di Desa Banyumulek. Metode yang digunakan dalam pengabdian ini adalah penyuluhan atau sosialisasi kepada para peserta. Kegiatan ini dilakukan dengan beberapa tahapan diantaranya :

1. Persiapan pelaksanaan kegiatan

Kegiatan ini diawali dengan koordinasi dan konsolidasi antara tim pengabdian dengan ketua karang taruna yang dibantu oleh mahasiswa yang sedang KKN di banyumulek. Koordinasi terkait persiapan kegiatan seperti bentuk kegiatan, waktu kegiatan, penetapan lokasi, dan jumlah peserta yang hadir mengingat kegiatan ini berlangsung selama pandemic yang tidak memungkinkan adanya kegiatan ramai dan berkerumun (Nurhayati et al., 2021)

2. Kegiatan penyuluhan berupa ceramah

Sebelum dilakukan kegiatan, tim pengabdian melakukan semacam pendekatan deskriptif kualitatif dengan menempatkan prinsip berpikir pada fenomena sosial yang terjadi di masyarakat. Seperti yang telah ditegaskan oleh (Cresswel, 2014);(Setiawan, 2018) yang menguatkan asumsi perspektif deskriptif untuk menakar kualitas variabel penelitian lebih menukik. Pengumpulan data dilakukan dengan menggunakan metode simak dengan teknik simak libat cakap.s Artinya, peneliti ikut terlibat dalam diskusi dan sebagai narasumber kegiatan dalam pengabian. Di samping itu, metode catat dengan teknik catatan kepustakaan, yakni melakukan saduran dokumentasi data yang ada di Desa Banyumulek. Penganalisisan data dilakukan dengan menggunakan kualitatif dengan teknik deskriptif. Kegiatan penyuluhan terkait tentang potensi desa, langkah pengembangan desa berbasis pasar digital pada wirausaha, dan produk pasar digital.

3. Evaluasi keberhasilan kegiatan

Kegiatan dievaluasi keberhasilannya dengan observasi secara langsung untuk melihat respon peserta terhadap materi yang diberikan. Observasi erat kaitannya dengan partisipasi, tingkat keseriusan serta jawaban dari pertanyaan yang diajukan oleh tim pengabdian (Hirsan et al., 2021; Nurhayati et al., 2020).

\section{Hasil dan Pembahasan}

Kegiatan penyuluhan ini dihadiri oleh sekitar 20 orang peserta yang terdiri karang taruna dan pemuda kaum milenial di desa Banyumulek. 
Kegiatan ini diapresiasi sangat antusias oleh para peserta, karena sangat mendukung dengan situasi dan kondisi masyarakat khususnya kaum milenial yang sangat haus akan informasi terkait digitalisasi. Kegiatan berlangsung sangat interaktif dilihat dari keaktifan para peserta bertanya kepada seluruh fasilitator yang merupakan tim pengabdian seperti yang terlihat pada Gambar 1.

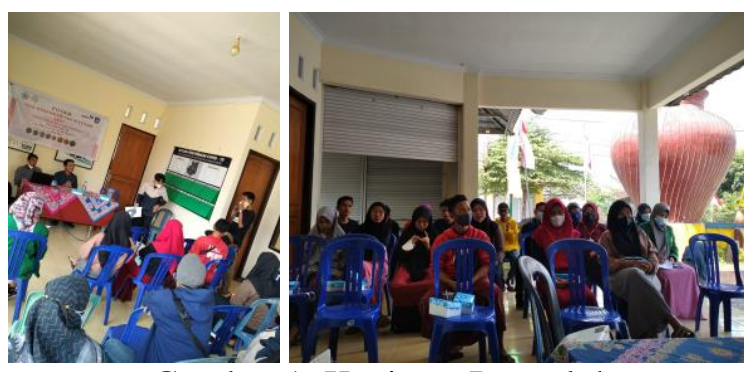

Gambar 1. Kegiatan Penyuluhan

Pembahasan Ketika penyuluhan meliputi deskripsi dan potensi desa, langkah pengembangan desa berbasis pasar digital pada wirausaha, dan produk pasar digital. Adapun deskripsi pembahasan sebagai berikut.

\section{Deskripsi dan Potensi Desa}

Desa Banyumulek sebagai salah satu desa yang terletak di Kecamatan Kediri Kabupaten Lombok Barat memiliki ruang lingkup wilayah desa yang cukup luas, terdapat 10 dusun dengan total 42 RT merupakan jumlah yang cukup besar untuk sebuah desa. Menurut asal kata namanya yaitu Banyumulek ada dua versi cerita rakyat yang pertama menyatakan bahwa nama Banyumulek berasal dari bahasa Jawa yaitu 'Banyu" yang artinya air dan "Mulek" berarti cantik karena memang dulu daerah Banyumulek ini merupakan langganan banjir (Kasfunnuri, 2021). Desa Banyumulek telah lama dikenal sebagai Desa Wisata hingga mancanegara memiliki beberapa potensi dan kekayaan yang cukup melimpah, di antaranya:

Kerajinan Gerabah. Ketika nama Desa Banyumulek disebut, hal yang pertama muncul dalam benak siapapun yang mendengarnya adalah istilah "Desa Gerabah". Begitu terkenalnya kerajinan gerabah di desa ini hingga Banyumulek selalu diidentikkan dengan gerabah. Awal gerabah Banyumulek ini mendunia adalah pada awal 1990 kerjasama antara Indonesia dengan Jaica (Japan International Corporation). Sepanjang jalan di
Desa Banyumulek sejak memasuki tapal batas desa, pengunjung akan disuguhi dengan melimpahnya hasil kerajinan gerabah di setiap rumah warga (Hadi \& Wirastomo, 2021). Hal yang paling istimewa adalah kerajinan gerabah ini merupakan hasil dari karya tangan dingin masyarakat Desa Banyumulek dan diturunkan dari generasi ke generasi. Pusat produksi dan pembuatan gerabah di Desa Banyumulek terletak di Dusun Muhajirin.

Masjid Kembar Menara Tunggal. Beberapa meter ke arah barat kantor desa Banyumulek terdapat sebuah tempat ibadah yang cukup unik yang dikenal dengan masjid kembar menara tunggal. Sesuai dengan namanya, masjid ini secara fisik terdiri dari dua masjid yang dibangun dengan bentuk dan rupa yang sama sehingga disebut kembar. Terletak di dua sisi yang berbeda, masjid kembar ini dihubungkan oleh sebuah penghubung di atas jalan yang nantinya akan dibangun sebuah menara tunggal yang akan menjadi salah satu bangunan monumental yang hanya ada di Desa Banyumulek (Nrartha, dkk, 2021). Menara tunggal melambangkan satu kesatuan. Masjid kembar menara tunggal merupakan wisata religi dengan tinggi menara yang akan dibangun adalah 63 meter di tengah desa yang terpisah oleh jalan desa. Awal mula masjid kembar menara tunggal ini ialah didirikan oleh masing-masing warga dua dusun setempat. Masjid Nurul Badi'ah di sebelah abarat berada di Dusun Karang Pande Banyumulek Barat dan Masjid Silaturahmi yang terletak di Dusun Mekar Sari. Jarak antara kedua masjid tersebut adalah sekitar 10-15 meter. Ceritanya, awal mulanya sekitar 50 tahun lalu, berdiri salah satu masjid yang diberi nama Masjid Nurul Badiah. Letaknya di Dusun Banyumulek Barat. Awalnya keberadaan masjid ini dimanfaatkan oleh warga setempat untuk beribadah dan sebagai pusat kegiatan keagamaan. Seiring berjalannya waktu, ada kesalahpahaman antar pemangku masyarakat kala itu. Dulu ada pemahaman sebagiaan masyarakat tidak mengerjkan sholat zuhur dan asar di masjid secara berjamaah satu kubu memiliki pemahaman tidak mengerjakansalat zuhur dan ashar di masjid, kubu kedua tetap mendirikan salat zuhur dan ashar di masjid. Perbedaan pemahaman ini, akhirnya sampai pada pembangunan masjid baru yang diberi nama Masjid Silaturrahmi (Vebriyanti, 2015). 


\section{Potensi berikutnya berupa Makam}

Tertua, menurut sejarah makam tertua di Desa Banyumulek adalah makam yang pertama kali dan tertua di Desa Banyumulek. Makam tertua ini terdapat 3 orang yang dimakamkan.

Sumur Tua, Sumur tertua ini terletak di Dusun Banyumulek Barat. Sumur tertua ini hingga sekarang masih dianggap keramat. Beberapa kepercayaan yang masih hidup di masyarakat adalah jika mencuci wajah di sumur itu maka akan sekedar mendapatkan jodoh. Jika ada yang terkena penyakit kulit semacam penyakit cacar maka apabila mandi air dari sumur tertua ini maka akan sembuh.

Terdapat potensi Taman Bunga, taman bunga Desa Banyumulek terletak di Dusun Gubuk baru, dengan luas sekitar 1,5 hektar. Rencana ke depannya area taman Bunga akan makin lengkap dengan beragam tanaman hias seperti Aglonema amorera, Aglonema lipstik, Aglonema sirih silver, Aglonema sirih irian, Aglonema begonia, Aglonema janda bolong, Aglonema amazon, Aglonema dona carmen, Aglonema lipstik calatia, Aglonema chiang may, Aglonema leg star dan Aglonema srikandi. Tanaman bunga ini menjadi sumber penghasil bunga untuk berbagai jenis kegiatan di Kota Mataram dan Lombok Barat. Misalnya untuk acara adat, agama, dan acara-acara hiburan lainnya.

\section{Pengembangan Pasar Digital}

Pasar digital merupakan paradigma wirausaha baru di era milenial. Muda-mudi banyak berkecimpung dalam usaha digital. Perkembangan pesat dapat disimak dari menjamurnya berbagai vendor aplikasi dan jasa promosi digital di Indonesia. Keberadaan ini tentu menjadi keuntungan bagi pengusaha desa atau lokal untuk memasarkan produknya. Kegiatan yang ditawarkan dalam penelitian ini berupa pendampingan secara intensif membangun jeajring digital dalam memasarkan produk lokal secara global. Seperti yang dilakukan di Desa Banyumulek, Lombok Barat.

Desa Banyumulek dengan beragam potensi yang dimililiki sangat tepat untuk memiliki pasar digital. Hal ini dikarenakan urgensi situasi dan kondisi masa pandemi dan sumber mata pencaharian masyarakatnya, rerata bersumber dari kerajinan gerabah dan usaha rakyat lainnya. Produk-produk yang dihasilkan rerata bergantung dari kerajinan. Pembangunan jejaring digital dalam memasarkan produk lokal Desa Banyumulek memerlukan mekanisme yang ideal. Berdasarkan sasarkaji dan proses di lapangan, mekanisme yang digunakan dapat disimak pada Gambar 2 . (bandingkan dengan skema yang diadaptasi oleh (Setiawan, 2020); Setiawan \& Mandala, 2021)kegiatan pendampingan di bawah ini.

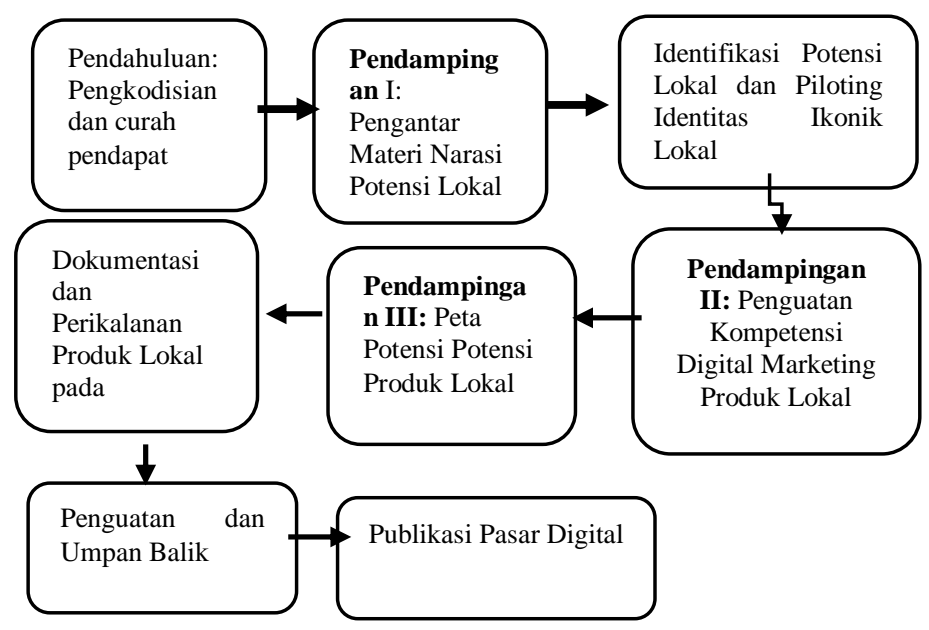

Gambar 2. Alur Pengembangan Pasar Digital/Digital Markeing di Desa Banyumulek

Gambar 2. di atas memuat skema perencanaan sampai dengan publikasi pasar digital di Desa Banyumulek. Proses pengembangan pasar digital didahului proses curah pendapat yang dilakukan di Kantor Desa Banyumulek pada Bulan September 2021. Kegiatan ini mengundang seluruh perangkat desa dan tokoh pemuda desa. Selain itu ini juga sangat erat kaitannya dengan kehadiran Bumdes yang memiliki peran penting di tengah masyarakat (Ibrahim et al., 2021). Kegiatan ini bertujuan untuk memperkuat konsep dan pemahaman mengenai pasar digital sebagai solusi wirausaha di masa pandemi. Pendampingan dilakukan sebanyak tiga kali sampai dengan terbentuknya pasar digital masyarakat Desa Banyumulek pada vendor-vendor pasar digital nasional, seperti Tokopedia dan Bukalapak.

Selanjutnya, beberapa solusi terhadap penyelesaian masalah yang terjadi, yakni (a) konstruksi narasi potensi desa, (b) workshop digital marketing, (c) konstruksi peta potensi desa, dan (d) pembuatan akun digital marketing di beberapa market place. Adapun rincian solusi yang ditawarkan sebagai berikut. 
a. Konstruksi Narasi Potensi Desa Banyumulek, dokumen Pustaka mengenai rangkuman seluruh potensi desa. Dokumen ini sebagai arsip desan dan bahan promosi desa dari waktu ke waktu.

b. Workshop Digital Marketing Produk Lokal, pelatihan langsung secara offline dengan sasaran utama para remaja dan pemuda dalam memanfaatkan media teknologi dan media sosial. Dilaksanakan selama 3 hari dengan pembagian konsep yang berbeda tiap harinya. Dengan hari pertama adalah fokus kepada pembuatan pamflet/brosur dengan aplikasi yang mudah digunakan seperti Canva, Picsart dan lainnya. Hari kedua sasarannya adalah pelatihan pembuatan video promosi terkhusus potensi Desa Banyumulek. Hari ketiga akan fokus pada penyelesaian hasil pembuatan pamflet/brosur dan editing video promosi potensi Desa Banyumulek.

c. Konstruksi Peta Potensi Desa, Penyusunan, peta potensi desa secara fisik berupa peta persebaran potensi yang akan ditempatkan dekat dengan tapal batas desa agar para pengunjung atau turis yang berdatangan akan mendapatkan informasi awal sebelum memasuki Desa Banyumulek di mana saja letak potensi dan pariwisata di Desa Banyumulek.

d. Literasi Pasar Digital dan Publikasi Wahana Wirausaha Milenial, Memperkenalkan media teknologi dan media sosial dalam mempromosikan potensi dan kekayaan Desa Banyumulek dalam dunia virtual. Mengingat di era 4.0 di mana setiap lini kehidupan tidak pernah lepas dari penggunaan teknologi dan media sosial. Kondisi ini harus bisa dimanfaatkan setiap celahnya.

\section{Produk Pasar Digital}

Produk pasar digital Desa Banyumulek meliputi beberapa produk penjualan, seperti komoditas utama, yakni gerabah dan pesona alam desa. Produk digital yang sudah berhasil dipublikasikan dan berjalan dari Oktober November 2021 berupa pasar digital gerabah di dua vendor nasional, yakni Tokopedia.com dan Shopee.co.id. Alasan dipilihnya, menurut Iprice.co.id (https://iprice.co.id/insights/mapofecommerce/), kedua e-commerse ini karena memililki pengunjung market terbesar di Indonesia, dan bahkan di Asia Tenggara. Adapun wujud pasar digital Desa Banyumulek sebagai berikut.

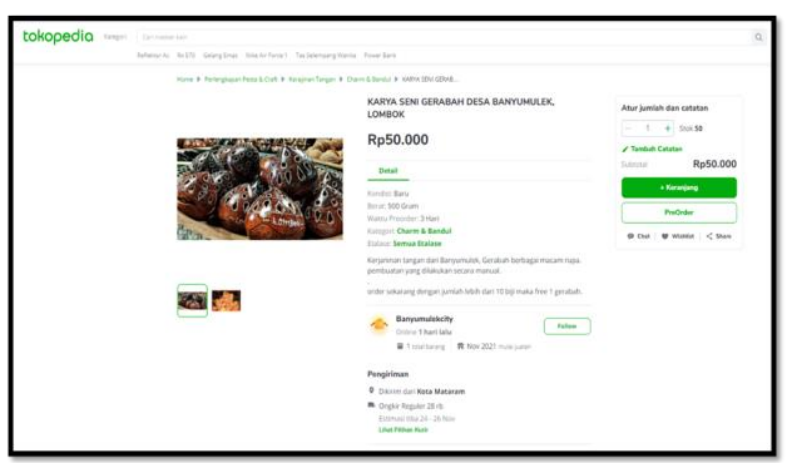

Gambar 3. Pasar Digital Gerabah Desa Banyumulek di E-Commerse Tokopedia.com.

Gambar 3 menunjukkan konten Pasar Digital Gerabah Desa Banyumulek, Lombok Barat. Wahana digital ini menjadi trobosan baru di Desa Banyumulek dalam memasarkan produk kerajinan dan pesona alam desanya. Salah satu gambar jualan yang ditawarkan di Tokopedia.com berupa kendi tempat aroma terapi ruangan. Produk ini biasanya diekspor, tetapi setelah pandemi Covid-19 melanda, produk ini menjadi kurang laku dan produksinya tertahan karena kegiatan ekspor yang dihentikan. Untuk itu, melalui pasar digital yang sudah berjalan beberapa bulan sudah membuahkan hasil, meski belum semasif, seperti keuntungan dari kegiatan ekspor produk. Jejaring penjualan produk lokal ini dapat diakes pada link https://www.tokopedia.com/banyumulekcity/karyaseni-gerabah-desa-banyumulek-lombok. Dipilihnya Tokopedia.com sebagai lokali pasar digital Desa Banyumulek karena Tokopedia.com memiliki pengunjung pasar per bulan mencapai 147.790.000 (sumber:

https://iprice.co.id/insights/mapofecommerce/).

Angka ini menjadi pringkat tertinggi pengunjung pasar online di Indonesia.

Pasar digital/digital marketing berikutnya, dibuka pada platform e-commerse Shopee.co.id. Kegiatan literasi pasar digital yang telah dilakukan juga berupaya menyasar berbaai pasar digital nasional lainnya. Hal ini dimaksudkan untuk memperkuat jejaring usaha warga Desa Banyumulek dalam menyelamatkan usaha gerabah dan usaha pesona alamnya. Terlebih, di tahun 2021 ini menjadi peluang bergeliatnya perekonomian lokal yang ditandai dengan berbagai perhelatan berskala nasional dan internasional di Lombok. Tentu hal ini menjadi peluang tersendiri untuk pasar digital Desa Banyumulek untuk terus 
berinovasi dan melakukan terobosan pemasara. Adapun corak pasar digital Desa Banyumulek di aplikasi Shopee.co.id, dapat disimak pada gambar 4 di bawah ini.

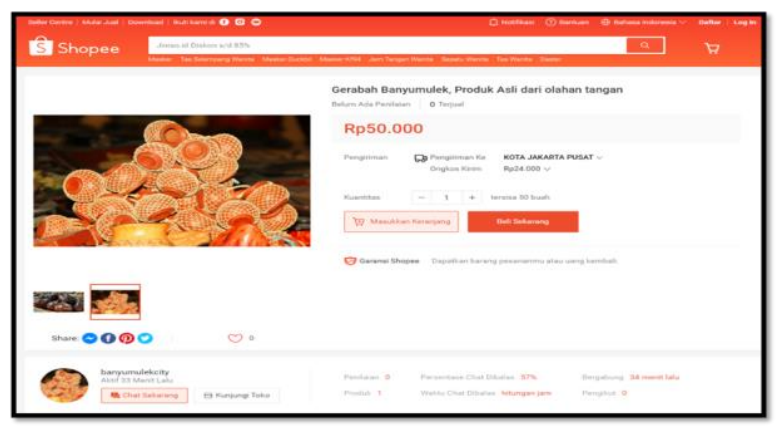

Gambar 4. Pasar Digital Gerabah Desa Banyumulek di E-Commerse Shopee.co.id

Gambar 4. memuat tampilan antarmuka pasar atau toko digital Desa Banyumulek di platform shopee.co.id. Lokasi e-commerse dipilih karena memiliki pengunjung mencapai 134.383.300 orang per bulan (sumber: https://iprice.co.id/insights/mapofecommerce/).

Data ini menjadi kedua tertinggi setelah Tokopedia.com yang menduduki pringkat tertinggi di Indonesia. Jejaring kunjungan pasar digital di Shopee.co.id dapat dikunjungi pada https://shopee.co.id/product/597482540/151026201 $\underline{42 / .}$

\section{Kesimpulan}

Peran pasar digital dalam masa pandemi Covid-19 sangatlah bermanfaat. Masyarakat Desa Banyumulek, Lombok Barat (NTB) mendapatkan solusi terhadap kondisi usaha lokal di desa yang mengamali vakum selama 1 tahun terakhir. Geliat perekonomian mulai dirasakan oleh para tokoh pemuda dan pelaku usaha di Desa Banyumulek, setelah kehadiran Tim Pengabdian Universitas Muhammadiyah Mataram. Tim menginisiasi pemebentukan pasar digital dengan basis pasar pada vendor marketplace nasional, seperti Tokopedia dan Shopee. Kedua, e-commerse ini menjadi lokasi pemasaran mengingat memiliki data pengunjung tertinggi di Indonesia. Produk pasar yang dipasarkan berupa hasil kearajinan gerabah, pesona alam, dan beberapa usaha pedesaan lainnya. Jejaring kunjungan dapat diakses

pada

link

https://www.tokopedia.com/banyumulekcity/karya

-seni-gerabah-desa-banyumulek-lombok dan

https://shopee.co.id/product/597482540/15102620

$\underline{142 / .}$.

\section{Saran}

Diperlukan pendampingan lebih mendalam terkait digitalisasi khususnya untuk marketing terkait potensi desa yang ada di banyumulek.

\section{Ucapan Terima Kasih}

Tim Pengabdian Kepada Masyarakat mengucapkan terima kasih kepada seluruh peserta dari kalangan karang taruna dan pemuda Desa banyumulek, yang sudah antusias hadir pada acara penyuluhan, mahasiswa KKN MAS kelompok 18. Bapak Kepala Desa dan jajaran yang telah menfasilitasi tempat kegiatan ini. Terima kasih pula disampaikan kepada Rektor UMMAT melalui LPPM UMMAT atas pendanaan Hibah Internal Pengabdian Kepada Masyarakat Tahun Anggaran 2021

\section{Daftar Pustaka}

Cresswel, J. W. (2014). Research design:Qualitative, quantitative and moxed method. In Sage Publications Inc.

Hadi, Sulhan, Nurul Hidayati Indra Ningsih, H. W. (2021). Pendampingan Tehnik Pemasaran Pada Pengrajin Gerabah Di Desa Banyu Mulek Kecamatan Kediri. Journal of Business Society, 1(1), 50-62.

Hirsan, F. P., Ibrahim, I., Salikin, S., Ghazali, M., \& Nurhayati, N. (2021). Pelatihan Pengelolaan Sampah Sisa Makanan Restoran Apung Berbasis Agen Biologi Black Soldier Fly (BSF). Jurnal Pengabdian Magister Pendidikan IPA, 4(3), Article 3. https://doi.org/10.29303/jpmpi.v4i3.979

Ibrahim, I., Nurhayati, N., Sulastri, Y., \& Ghazali, M. (2021). Pendampingan Kemitraan Program Teknologi Tepat Guna Dengan Badan Usaha Milik Desa. MATAPPA: Jurnal Pengabdian Kepada Masyarakat, 4(4), 531. https://doi.org/10.31100/matappa.v4i1.129 0 
Nurhayati, N., Asmawati, A., Ihromi, S., Marianah, M., \& Saputrayadi, A. (2020). PEMBERDAYAAN EKONOMI MASYARAKAT MELALUI APLIKASI TEKNOLOGI PENGOLAHAN DODOL NANGKA DAN SUSU BIJI NANGKA DI KABUPATEN LOMBOK BARAT. SELAPARANG Jurnal Pengabdian Masyarakat Berkemajuan, 4(1), 522-528. https://doi.org/10.31764/jpmb.v4i1.3321

Nurhayati, N., Sulastri, Y., Ghazali, M., \& Ibrahim, I. (2021). PENYULUHAN CARA PENGOLAHAN PANGAN YANG BAIK UNTUK PERBAIKAN PROSES PRODUKSI DAN MUTU MINYAK KELAPA DI IKM SAKRA TIMUR LOMBOK. JMM (Jurnal Masyarakat Mandiri), 5(1), 152-160. https://doi.org/10.31764/jmm.v5i1.3502

Setiawan, I. (2018). Verba Lempar Bahasa Sasak: Kajian Metabahasa Semantik Alami. Jurnal Ilmiah Telaah, 3(1), 1. https://doi.org/10.31764/telaah.v3i1.222

Setiawan, I. (2020). Leksikon Gender Bahasa Sasak: Analisis Semantik Komponensial. Salingka, $16(2), \quad 143$. https://doi.org/10.26499/salingka.v16i2.261

Setiawan, I., \& Mandala, H. (2021). Morfologiteks Debat Calon Presiden Republik Indonesia Periode 2014 - 20192014 2019. Jurnal Ilmiah Telaah, 6(1), 82-92. https://doi.org/10.31764/telaah.v6i1.3869 